\title{
Nationalist Action Party and the Politics of Dissent
}

\author{
Derya Kömürcü, PhD.
}

Department of Political Science and International Relations, Yıldız Technical University Email: deryakomurcu@gmail.com

Gökhan Demir, PhD.

Department of Political Science and International Relations, Yıldız Technical University Email: gokhandemir11@gmail.com

\section{Doi:10.5901/mjss.2014.v5n8p552}

\section{Abstract}

All political parties tend to use different types of discourses to legitimize themselves and to mobilize their supporters. These discourses may not properly fit to their ideologies, but as they seek the support of the vast majority of society, they may refer to the policies and values of other ideological camps. In Turkey, the MHP is the most influential actor of extreme right politics. Its ideology depends on nationalism and Turkishness and the party mobilizes a considerable population by appealing to nationalist feelings. On the other hand, the MHP tries to transform itself into a vote-seeking catch-all party and aims to broaden its social base. For this reason, MHP's political strategy combines nationalist and conservative values with rather moderate ones and even 'leftist' ones. Our study which focuses on the political discourse that the MHP has adopted in the last four general elections demonstrates that elements that can be considered as "leftist" are also a part of the MHP discourse.

Keywords: Nationalist Action Party, the MHP, Turkish Nationalism, Political Discourse, Turkish Politics

\section{Introduction}

Political parties are formal organizations that represent the aims and interests of different socio-economic forces in the political sphere. Parties seek to organize and dominate the organs of government and to provide national leadership. Conflicts among different groups are expressed through political parties, which represent a democratic translation of interests. Parties connect the citizenry and the governmental process and aggregate demands into loosely coherent policy packages. They are crucial to decision making and its implementation (Klingemann et al., 1994: 169-170). However, institutionalization of political parties is not the sole property of political sphere in order to provide the survival of the social system. Beside institutionalization, they should also have a moral grounding. The nature of politics is pragmatic and parties need first of all to legitimize and then to reproduce themselves.

In this study our principal stand point is the fact that all political parties or in a much more comprehensive domain all political currents tend to use different types of discourses to legitimize themselves and to mobilize their supporters. These discourses may not properly fit to their fundamental ideologies, but as they seek the support of the vast majority of society, they have to use such discourses in a pragmatic and instrumentalist way. Since the emergence of catch-all and vote-seeking parties, these political actors tend to be more pragmatic and try to appeal to a broader audience (Kirchheimer, 1990; Wolinetz, 2002).

In this paper, we will examine the Nationalist Action Party (MHP) of Turkey and try to find out some "leftist" elements in the party's discourse. We believe that the MHP is an appropriate example to study the juxtaposition of different ideological discourses to effect the voting behaviour of voters, because on the one hand, it is an extreme right wing party with nationalist, ethnicist and even racist ideological references, but on the other hand it is a vote-seeking party trying to reach all the segments of society. The MHP aims to become a much more moderate party that covers almost every social stratum by uniting them around the great ideal of Turkish nationalism, but in order to be successful in this unification, they use different ideological discourses. For this reason, we claim that the MHP as being an extreme right-wing party not only adopts an ideological discourse that includes right-wing slogans, goals and projects, but also refers to the leftist or liberal notions.

In the light of this claim, our aim in this study is to examine whether the discourse that the MHP has adopted in different election campaigns contained some 'leftist' components. The article analyzes MHP's ideological characteristics 
and historical development as well as the election strategies, slogans and the party documents. Our principal materials of analysis are the Programme of the Nationalist Action Party, its election declarations and other documents on specific issues that are complementary of election declarations. We have applied a content analysis to these documents and besides well-known "leftist" slogans, we tried to read the subtexts of them.

Nevertheless, while we were trying to determine the general framework of that "leftist" discourse, we took into consideration the sui generis characteristics of Turkish politics: within the mainstream political currents of Turkish politics, there has never been a liberal tradition that is similar to those in Western democracies. In Turkey, right-wing politics have always been more close to conservatism than liberalism. That's why many political demands that can be named as liberal become a part of "leftist" discourse in the Turkish context. For example, the notion of rights that is closely related with liberalism in Western societies, have formed an important part of leftist politics in Turkey. In this sense, we considered some liberal slogans, goals and projects that the MHP has used in its election campaigns as elements of a "leftist" discourse. Traces of anti-capitalism, anti-imperialism, critiques of social, cultural, economic or international policies offer us some clues to determine the leftist elements in the ideological discourse.

\section{Historical Background the Transformation of the MHP}

The MHP is the successor of the Republican Peasants' Nation Party (Cumhuriyetçi Köylü Millet Partisi - CKMP) which was founded in 1948 by General Fevzi Çakmak. The CKMP took the support of small fascist and proto-fascist groups as well as peasants and middle classes. Its ideology contained corporatist, developmentalist, and modernist components while taking nationalism as the main ideological reference. The party's popular support was very limited and it could not play a significant role in the political arena (see Çınar and Arıkan, 2002: 26).

In 1965, with the election of former colonel Alpaslan Türkeş as the party leader, the CKMP adopted a Turkist and anti-Communist discourse with some Islamic references. In 1967 the programmatic text of Türkeş's "Nine Lights Doctrine" (Dokuz Işık Doktrini) has become the doctrine of the party and in the Extraordinary party congress that was held in Adana on 8-9 February 1969, the name of the party was changed from CMKP to MHP. The 9 tenets of the MHP were nationalism, idealism, moralism, communitarianism, positivism, libertarianism and character-building, ruralism, developmentalism and populism, and industrialism (Türkeş, 2010). "The party's strong anti-capitalist and anti-masonic stance was also reduced, a tribute to the workings of the forces of the system, which increasingly considered the MHP as a legitimate force because of its stringent anti-Communism" (Arıkan, 1998: 123-124).

In the 1960s and the 1970s it was the mission to "protect the state" that characterized the MHP. Their acts and policies were totally anti-communism oriented. The movement has identified itself with the state. It was acting in the name of the state and was one of the most important actors of the terror period in the second half of the 1970s (Başkan, 2006: 87). On the hand, as Table 1 shows, MHP's popular support remained limited and the vote of the party did not reach to a significant level until the late 1990s.

Table 1: MHP Votes in Turkish Elections

\begin{tabular}{|c|c|c|c|}
\hline & Date & Votes (\%) & Number of Seats \\
\hline CMKP & 1965 & 2.2 & 15 \\
\hline MHP & 1969 & 3.0 & 1 \\
\hline MHP & 1973 & 3.4 & 3 \\
\hline MHP & 1977 & 6.4 & 16 \\
\hline MÇP & 1987 & 2.9 & - \\
\hline MÇP & 1991 & 16.9 & $62^{*}$ \\
\hline MHP & 1995 & 8.1 & - \\
\hline MHP & 1999 & 17.9 & 129 \\
\hline MHP & 2002 & 8.3 & - \\
\hline MHP & 2007 & 14.2 & 71 \\
\hline MHP & 2011 & 13 & 53 \\
\hline
\end{tabular}

After the period that began with the military intervention of 12 September 1980, the party sought to redefine itself. Coup d'état was not only against the "leftist-revolutionary" movements but also against the idealist [ülkücü] movement. They

* Of these 62, only 19 seats in effect belonged to the MÇP since the MÇP, the Welfare Party and the Reformist Democracy Party had made an electoral alliance at these elections. 
widely argued that "We are in prison, yet our ideology is in government." So they criticized their political strategy of the 1970 s and put a distance between the idealist movement and the state. Many of idealists believed that the state used them as a weapon against revolutionaries and when everything has finished, they were all thrown into prisons.

In the 1980s the components of the MHP ideology have started to change. Islam played a more important role in the party and Turkish Islam Synthesis became the dominant ideology of the party. This transformation brought some critiques to the state and the regime and opened the way to a much more radical change that formed the identity of the party in the 2000s. They claimed that the reason of existence of the MHP was not only anti-communism and it had its own ideals and goal of power.

Consequently, in the 1999 general elections the MHP came out as the second party by obtaining approximately 18 per cent of the votes and managed to be a part of the coalition government between 1999 and 2002. According to Başkan, the process of globalization has been a factor contributing to the rise of the MHP in the late 1990s. For her, "the MHP got its support primarily from rural areas of central and eastern Anatolia, and then from low-income settlements of big cities. Farmers, small merchants, and the unemployed, who were marginalized in the process of globalization, constituted the socio-economic strata of the party's electorate in the 1999 general elections. In other words, the 'losers' of the globalization process in Turkey composed the backbone of the MHP's voters in this election" (2006: 89).

Another underlying political and ideological dynamic that have brought the MHP to the point of government was the Kurdish issue. The ongoing war with Kurdish rebels caused the rise of nationalism and militarism and a decline of trust to the mainstream political parties (Bora, 2003). In this context, critiques that take aim at the state allowed the emergence of anti-capitalist and anti-imperialist discourses. When the party abandoned the mission to protect the state, anti-capitalist discursive elements, that are important components of nationalist and fascist movements in the world, could find a place in the electoral strategy of the MHP as a tool to reach the people.

It is well-known that in the development period of fascism in both Germany and Italy, "leftist" components were highly effective on the ideological discourse of fascist movements. First of all, there has always been a social radicalism in the fascist movements. Fascism often "considered itself a form of socialism, freed of humanitarian sentimentalism and Marxist dialectic, truer to fundamental socialist aims in that it tried to adapt itself to a changing historical reality which the old Marxist interpretation no longer suited" (Weber, 1964: 29). When socialism or "leftist" politics is considered as opportunistic and empirical, thus utilitarian, its combination with nationalism is possible. "Mussolini in Italy, Hitler in Germany and Péron in Argentina, all claimed that they had revivified socialism and given it a new efficacy and a fresh connection with historical evolution" (Weber, 1964: 31).

More precisely, in the ideology of fascism there are anti-capitalist and anti-regime elements which are important parts of the leftist discourse. According to Nicos Poulantzas (1974), these elements are inherited from petite-bourgeois ideology and the active supporters of fascist and nationalist movements are lower classes of petite bourgeoisie. However, anti-capitalist elements that are present in the petite-bourgeois ideology are not opposed to the essence of capitalism.

On the other hand, Ernesto Laclau raises an objection to the idea that the anti-capitalism of fascism depends directly to the class positions (petite-bourgeois) of those who support fascist and nationalist ideologies. He distinguishes the level of social formation from the level of economic relations. At the level of social formation, contradiction between dominant bloc and dominated people is more determinant than economic conflicts. So, the social source of fascist and nationalist political movements is associated with the contradiction between dominant bloc and people, more than class conflicts (1977, 81-142).

Returning back to the MHP's transformation and emergence of "leftist" components in its discourse, in 1970s the party did not have the perspective to take the power into its hands. That's why nationalist and anti-communist discourses were sufficient to mobilize the supporters of the party. However, in the 1980s with the re-organization of the party cadres and the reformulation of the ideology, the MHP gradually left the identity of "a party of ideology" and became a "catch-all" party (Gunther and Diamond, 2003). In 1997, after the death of the party leader Alpaslan Türkeş, Devlet Bahçeli has become the new MHP leader. It was Bahçeli who made the first reformulation in the Party Programme. In 1987 he became secretary-general of the MHP and made the Party Programme relatively more 'flexbile'. The intervention of Bahçeli and his cadres caused modernizing effects on the practice and discourse of the party. Their aim was to establish expert cadres instead of militants, a scientific discourse instead of an agitative one and a professional type of policymaking (Bora and Can, 1994: 276-279).

Especially after 1991, Islam has become a less important component of the party ideology and the MHP has adopted a more secular nationalism that was articulated to Kemalism. The MHP, on its way to become a moderate rightwing party, tried to create elite cadres that could represent the party in every domain of the political and social life. Successively in 1994 local elections and in 1995 general elections it was seen that party has a fixed number of voters that is not under 8 per cent. After the 1995 elections there were two ways to go for the MHP. It would either compete with 
the Welfare Party (Refah Partisi, RP) for the conservative votes to reach the 10 per cent national threshold or turn towards a field, which was emptied by crisis of the center right and center left parties.

As Çınar and Arıkan puts it, "the changes the MHP faced with the new leadership were not limited to public image. (...) The change of leadership in 1997, the unprecedented increase of voter support in 1999 (which even surprised the MHP itself), and its experience as a major coalition partner after this increase, forced the MHP to review its main ideological principles, reinforcing some of the changes that had begun since the last years of Alpaslan Türkeş" (2002: 34). The MHP placed itself insistently far from a radical ideological-political position and tried to follow a stabilizing, pragmatist, reel-political perspective under the leadership of Bahçeli. This perspective aimed to cover nearly all the political discourses that are "available" for the party. Bacık considers this as a "vague party identity that amalgamated different, even contradictory, elements such as Islam, folk nationalism, secularism, militarism, Kemalism, statism, and even Ottomanism" (2011: 172). The section below demonstrates that some "leftist" elements can be added to this list.

\section{3. "Leftist" Elements in the MHP Discourse}

After briefly summarizing the transformation of the MHP in the 1980s and 1990s we can now follow the trails of "leftist" elements within the party discourse. At the base of idealist movement there are radical populist factors that are against the capitalist modernization process and its cultural alienation. That's why primary element of the leftist discourse within MHP's electoral strategy is a moderate type of anti-capitalism. Anti-capitalist elements of the MHP discourse can be widely seen at the cultural level. The party considers Westernization and Western culture identical with capitalization and thus, is against the cultural consequences of capitalization. As an alternative to westernization and the western culture, Turkish nationalists always put an emphasis on the Turkish culture (MHP, 2009: 104).

In fact, the MHP's anti-capitalist discourse refers to petty bourgeois ideology and is not opposed to the nature of capitalism. It is against excessive richness, inequitable distribution of income, and the problems that are related to the inconsistency of the capitalist system. For example in both the 1999 election declaration and "the Program of the Struggle with Poverty", nationalists defend an economy that is not based on speculative, unearned income, but on investment and production (MHP, 1999a:3; 1999b). By creating stable economic growth and a powerful production economy, the MHP aims to form a social welfare order which produces wealth, creates employment and assures that all sections of society gets a just share depending on its contribution to the value created (MHP, 2002: 56; 2007: 8; 2009: 61). The MHP's economic model depends on the regulative and interventionist role of the state. According to this idea, state should intervene to the market to protect the citizens from monopolistic capitalism. Determination of wages, employment and prices should be controlled by the state. MHP's criticism of capitalism depends on the fact that it is "extremely" individualistic, liquidates small investors, monopolizes and internationalizes the capital. Capitalism is also accused for removing the solidarist, corporatist functions of the state.

Naturally, corporatism does not necessarily imply a 'leftist' content. The type of corporatism is extremely important to consider a party's discourse as "leftist". In political theory, there have been many leftist currents which defended a corporatist society as a step to transform the society and re-organize economic relations. However, in its nature corporatism cannot be necessarily associated with the "left". The main point in the MHP concerning the corporatism issue is that the idea of rejection of the existence of classes in Turkish society, that forms the basis of corporatist conception, is the most powerful link between MHP's official discourse and its social base.

The 1998 Party Programme of the MHP offered a corporatist conception of society. There was an emphasis on the notion of nation that eliminates class differences. In the Party Programme, there was a corporatist assembly project, which would be composed of representatives of six social pillars. These pillars were peasants, artisans and craftsmen, workers, functionaries, self-employed persons and employers. All these are the parts of Turkish nation that have same ideals and aims. According to Turkish nationalists, capitalism, communism or any other Western system is not appropriate to realize these national ideals and aims (MHP, 1998). On the other hand, in 2009 the party programme was amended and the project based on the ideal of a corporatist assembly representing six social pillars was abandoned (MHP, 2009).

As Arıkan puts it, "the MHP discards capitalism on the grounds that it is individualist, fosters cosmopolitanism and because it strongly rejects interventionism. The rejection of capitalism is based on the phrase 'big fish eat small fish', and the small fish is Turkey while the big industrialists and western capital are the big fish. It is capitalism, under the mask of democracy, that is responsible for the poverty and backwardness of Turkish society" (1998: 129).

Another important "leftist" element within the MHP discourse is anti-imperialism, which is directly linked with the 12 September 1980 military intervention. MHP's evaluation on the 12 September coup d'état totally concentrates on the role of the United States. That's why the discourse of the 1980s, which was against the military intervention also contained 
anti-imperialist components. For example the military intervention is interpreted as a "shield that was formed against antiimperialists who fought for their rights and who wanted to live independently" (Bizim Ocak, 1989 quoted in Bora and Can, 1994: 352).

Anti-capitalism and anti-imperialism go hand in hand in the ideological discourse of the MHP. They are both taken into consideration by using a cultural nationalist theoretical framework. Cultural nationalism refers to both anti-capitalist and anti-imperialist discourses which appear at the cultural level. The transformation that Turkey had experienced in the 1980s and the 1990s, the domination of the American culture on Turkish society forced the MHP to build up a counterdiscourse in this hegemonic struggle. In this context, it can be claimed that the theoretical publications of the MHP often defend a model of "Japan modernization", by referring to Ziya Gökalp's writings. In other words, they want to take only the technological-economic dynamics of the West and protect the existing socio-cultural structure (for more detail on Gökalp see Parla, 1985).

After this general framework on the "leftist" discourse of the MHP, we can now concentrate on more specific examples that are taken from the MHP's election campaigns. First of all there are some notions that form the base of MHP's election strategy. It is claimed that there is a dissatisfaction within the society and the MHP implies that it is the unique party that can solve these problems. In all election declarations there is an emphasis on the potential of Turkey to become a "Leader Country" of the world with its nation (MHP, 2002: 13-14; 2007: 5; 2009: 131; 2011: 6).

Here what is important for our study is to find out what kind of problems does the MHP determines as causes of the dissatisfaction of society. They are the unjust distribution of income, unlawfulness and poverty, which cause a social disharmony in the society (MHP, 1999a: 1). The party aims for political, economic and social stability and a struggle against poverty, unemployment and corruption (MHP, 2002: 16; 2007: 8; 2011: 23). In fact, these are the main issues that a left-wing party claims to deal with. The MHP claims that it can solve these problems because it is "national, democratic, powerful, just and honest." Nationalists argue that the MHP is the only party to meet the needs of Turkish people. Here, Turkish people is described as a unity that live in fraternity and looks for a developed, wealthy, peaceful society. It is harmonious by nature and it has shared goals.

At the economical level, there is not much evidence of a "leftist" discourse. As the MHP has transformed from a nationalist movement to a catch-all party that aims to capture the government, the party needs to get the consent of capitalists as well. For example they declare that free enterprises are the biggest wealth for a country but they also mention that these enterprises should operate for the sake of social liberty, peace and solidarity (MHP, 1999a: 5). Solidarity notion is essential for the ideology of the MHP. It involves both nationalist and "leftist" references. According to the MHP, "the culture of solidarity or Turkish socialism" [Türk toplumculuğu] is necessary to realize a just distribution of wealth between different strata of Turkish society. The culture of social solidarity is the main component of social peace (MHP, 2002: 18; 2007: 12; 2011: 23; 2009: 25).

As Öniş points out, "the MHP's economic programme looks fundamentally like a typical left-of-centre social democratic programme. It stressed the need to build a competitive national economy that would be able to compete on a global basis, and state intervention to curb corruption and build a functioning market economy" (2003: 50). Öniş also claims that "the party's approach to globalization resembles the characteristics of European style 'third way politics'. What is being criticized is not globalization per se, but its inegalitarian nature both within and across countries. The natural corollary of this position is to develop mechanisms that would result in more balanced patterns of globalization at the national and international levels. This conforms to the perspective of a 'third way' style social democratic politics" (2003: 44).

The MHP also favours tax reductions for the lower and lower-middle classes, and claims that the minimum wage has to be allowed against tax. Taxes have to be collected according to the capacity of citizens. The party argues that tax paying is a national duty and a matter of social responsibility (Arıkan, 1998: 128-130).

One may distinguish elements of a "leftist" discourse that is mixed with a populist one at the political level. The MHP stresses the eminence of Turkish nation, the importance of nationalism for the solution of all problems. In addition to that, rather than concrete programs, the party always position itself against an enemy, such as the PKK, Greece, etc. and do not pay much attention to issues such as democratization, human rights, and ecological problems.

Democratization is declared as one of the main goals of the MHP. The party, first aims to strengthen national unity and cooperation and then, make democratization real. The MHP's attitude about democratization is as follows: "Democracy is not only a political regime, but also a way of life. Our party believes in the necessity of democratization of social and political life. In order to transform our Constitution to a real "Social Contract", it has to be revised and necessary regulations should be made" (MHP, 1999a: 5; 2002: 109; 2007: 17-18; 2011: 34; 2009: 40.). The party also put an emphasis on human rights and ecological problems as well as the superiority of law. 


\section{Conclusion}

Although the MHP has gone through a drastic change since the late 1990s, the party continues to be the most influential actor of extreme right in Turkish politics. Its ideology primarily depends on nationalism and Turkishness and it can easily mobilize a considerable population by appealing to nationalist feelings. State, Turkish flag and motherland as well as Islamic culture are unquestionable values of the nationalist movement.

However, under the leadership of Devlet Bahçeli, the MHP adopted a political strategy that is different than the pre1980 period. From a movement and ideology party, the MHP has tried to transform into a vote-seeking catch-all party and aimed to broaden its social base. Parallel to this goal to appeal to different social groups, MHP's political strategy was to combine its nationalist and conservative values with rather moderate ones and even 'leftist' ones.

Our study which focuses on the political discourse that the MHP has adopted in the last four general elections (1999, 2002, 2007 and 2011) demonstrates that elements that can be considered as "leftist" are a part of the MHP discourse alongside nationalist and conservative ones. One of these "leftist" elements is an emphasis on social justice and just distribution of income. Egalitarian and anti-plutocratic elements are also evident. Another component of the MHP discourse is a limited critique of capitalism. This anti-capitalist discourse of the MHP reflects a reaction to individualism, competition and a society based on the political economic struggles between the classes. The party sees Turkish society as an organic whole functioning in harmony (Arıkan, 1998). And finally, time to time an anti-imperialist discourse that also has an anti-globalist vein appears within the MHP discourse.

\section{References}

Arıkan, E. B. (1998). The Programme of the Nationalist Action Party: An Iron Hand in a Velvet Glove? Middle Eastern Studies 34(4), $120-134$

Başkan, F. (2006). Globalization and Nationalism: The Nationalist Action Party of Turkey. Nationalism and Ethnic Politics 12(1), 83-105.

Bacık, G. (2011). The Nationalist Action Party in the 2011 Elections: The Limits of Oscillating Between State and Society. Insight Turkey 13(4), 171-187.

Bora, T., \& Can, K. (1994). Devlet Ocak Dergâh: 12 Eylül'den 1990'lara Ülkücü Hareket. (3rd edition) Istanbul: Iletişim Yayınları.

Bora, T. (2003). Nationalist Discourses in Turkey. The South Atlantic Quarterly 102(2-3), 433-451.

Çınar, A. \& Arıkan, B. (2002). The Nationalist Action Party: Representing the State, the Nation or the Nationalists? Turkish Studies 3(1), $25-40$.

Gunther, R \& Diamond, L. (2003). "Species of Political Parties: A New Typology", Party Politics, 9 (2), 167-199.

Kirchheimer, O. (1990). Catch-all Party. In Peter Mair (ed.), West European Party System. Oxford: Oxford University Press, pp. 50-60.

Klingemann, H. D., Hofferbert, R. \& Budge, I. (1994). Parties, Policies and Democracy. Boulder, co: Westview.

Laclau, E. (1977). Politics and Ideology in Marxist Theory: Capitalism, Fascism, Populism. London: New Left Books.

MHP (1998). Milliyetçi Hareket Partisi Programı [Party Programme of the Nationalist Action Party]. Ankara.

MHP (1999a). Milliyetçi Hareket Partisi 18 Nisan 1999 Seçim Beyannamesi [Nationalist Action Party's 18 April 1999 Election Declaration]. Ankara.

MHP (1999b). "Yoksullukla Mücadele Programı" [The Programme of the Struggle with Poverty]. Ankara.

MHP (2002). Milliyetçi Hareket Partisi 3 Kasım 2002 Seçim Beyannamesi: Türkiye'nin Onurlu Geleceği [Nationalist Action Party's 3 November 2002 Election Declaration: Honorable Future of Turkey]. Ankara.

MHP (2007). Milliyetçi Hareket Partisi 22 Temmuz 2007 Seçim Beyannamesi: Millî Duruş ve Kararlıık Belgesi [Nationalist Action Party's 2007 Election Declaration: Document of National Stance and Determination]. Ankara.

MHP (2009). Milliyetçi Hareket Partisi Parti Programı [Party Programme of the Nationalist Action Party]. Ankara.

MHP (2011). Milliyetçi Hareket Partisi 2011 Seçim Beyannamesi: 2023'e Doğru Yükselen Ülke Türkiye Sözleşmesi [Nationalist Action Party's 2011 Election Declaration: The Contract of Rising Turkey Towards 2023]. Ankara.

Öniş, Z. (2003). Globalization, Democratization and the Far Right: Turkey's Nationalist Action Party in Critical Perspective. Democratization 10(1), 2003: 27-52.

Parla, T. (1985). The Social and Political Thought of Ziya Gökalp: 1876-1924. Leiden: Brill.

Poulantzas, N. (1974). Fascism and Dictatorship London: New Left Books.

Türkeş, A. (2010). Dokuz Işık [Nine Lights]. Istanbul: Bilgeoğuz Yayınları.

Weber, E. (1964). Varieties of Fascism. New York: D. Van Nostrand Company.

Wolinetz, S. B. (2002). Beyond the Catch-all Party: Approaches to the Study of Parties and Party Organization in Contemporary Democracies," in Juan Linz, Jose Ramon Montero and Richard Gunther (eds.). The Future of Political Parties. Oxford: Oxford University Press, pp. 136-165. 